\title{
THE TRADITION OF TAREKAT QADIRIYAH WA NAQSABANDIYAH IN PEKANBARU, RIAU
}

\section{Masduki}

UIN Sultan Syarif Kasim Riau

masdukiafandi@gmail.com

\section{Toni Hartono}

UIN Sultan Syarif Kasim Riau

tonihartono1978@gmail.com

\author{
Imron Rosidi \\ UIN Sultan Syarif Kasim Riau \\ imronrosidi@gmail.com
}

\begin{abstract}
This article describes the tradition practiced by the followers of Qadiriyah wa Naqsabandiyah in Pekanbaru, Riau. By employing a qualitative approach, this article finds that that the tradition of the Tarekat Qadiriyah wa Naqsabandiyah in Pekanbaru, Riau emerged from the tradition (custom) performed at Pondok Pesantren Nurul Huda alIslami. Through the pesantren, the tarekat tradition is spread gradually in the practice of education and socialization. From the tradition of pesantren education, this tarekat philosophy is then socialized to the surrounding community's environmental traditions. Philosophically, this study also concluded that tarekat is a doctrine that is close to Islamic education. Pesantren as the center of tarekat development becomes 'icon' development of Islamic education based on Sufi character. In the contemporary context, the values of Sufi education are increasingly crucial, especially in responding to the patterns and lifestyles of consumptive ones arising from modernization, capitalism, and globalization.
\end{abstract}




\section{Abstrak}

Artikel ini menjelaskan tentang tradisi yang dianut oleh para pengikut Tarekat Qadiriyah wa Naqsabandiyah di Pekanbaru, Riau. Dengan metode kualitatif, kajian ini menemukan bahwa tradisitarekat Qadiriyah wa Naqsabandiyah di Pekanbaru, Riau muncul dari kebiasaan yang dilakukan di Pondok Pesantren Nurul Huda al-Islami. Melalui pesantren $i t u$, tradisi tarekat disebarkan secara gradual dalam praktek edukasi dan sosialisasi. Dari tradisi edukasi pesantren, kebiasaan tarekat ini kemudian disosialisasikan ke tradisi lingkungan masyarakat sekitar. Secara filosofis, kajian ini juga menyimpulkan bahwa tarekat merupakan ajaran yang dekat dengan pendidikan Islam. Pesantren sebagai pusat pengembangan tarekat menjadi 'ikon' pengembangan pendidikan Islam yang berkarakter sufistik. Dalam konteks kekinian, nilai-nilai pendidikan sufitik semakin krusial terutama dalam merespon pola dan gaya hidup konsumtif yang berkembang akibat modernisasi, kapitalisme, dan globalisasi.

Keyword: Sufi, Tradisi, Qadiriyah wa Naqsabandiyah

\section{A. Introduction}

The life of Sufism has actually been found since Prophet Muhammad saw. (Peace be Upon Him) and then forwarded by his companions, the tabi'in (Muhammad's companion) and tabi 'tabi'in (Muhammad's companion's followers). In the history of the development of Sufism, the figure known as the great Sufi after the Prophet Muhammad's companion (Tabi'in) was Abu Hamzah in Baghdad. Also known are some of the mystical figures such as Abu Yazid al-Bustami, Junaid al-Baghdadi and others. Some of the Sufi figures have established the Sufi orders such as Syadzily, Naqsyabandi, Samman, Rifa'i, Qusyasyi, and others. ${ }^{1}$

The tarekat (Sufi Order) is an important proof for the existence of Sufism. According to Julian Baldick, the concept of the tarekat is often identified as Sufism. Tariqa is considered as a method or path of a person to get closer to his God. This can be done by effort according to the instructions and steps taught in the tarekat leader, but also the closeness to God can be obtained from God's gift. ${ }^{2}$ That's why the Sufi figures use the

${ }^{1}$ Nur Syam, Tarikat Petani: Fenomena Tarikat Syattariyah Lokal (LKiS: Yogyakarta, 2013), p. 71

${ }_{2}^{2}$ Julian Baldick, Mystical Islam: An Introductuion to Sufism, (New York University Press: New York and London, 1992), p. 18 
tarekat to facilitate their followers in reaching self-approach to God and making it as a community or a particular group.

The study of the tarekat has indeed been done. There are at least four typologies of research done, namely: The first is the tarekat in relation to a very profane socio-political world. Research on this variant among others are done by Nur Syam in the topic of Disobedience of the Tarekat followers, Mahmud Sayuti with the topic of the Politic of Qadiriyah wa Naqsyabandiyah Sufi Order (Tarekat) in Jombang, Ajid Thohir with Political Movement of the Tarekat People, and Sartono Kartodirdjo with Banten Farmers Rebellion 1888. The second is the tarekat focused on the socio-economic world such as the study of Rajasa Mu'tashim in the topic of Business of the Sufis. The third is the study of the tarekat which focuses on doctrine and its spread, such as Martin van Bruinessen's study on Tarekat Qadiriyah wa Naqsyabandiyah in Indonesia. The fourth is the tarekat in relation to the social culture, such as Simuh on Javanese Sufism. Thesestudies of the tarekat are used as literature resourcesin this article. Currently, research on Sufi was more dominated and focused only on the regions of Java, such as Martin van Bruinessen's research.

The problem of this study is how tradition is done by followers of Tarekat Qadiriyah wa Naqsabandiyah in Pekanbaru, Riau? Does this Tarekat have a different tradition to that of in Java? Answering the question, this article attempts to describe the tradition of the tarekat followers practiced in Pekanbaru Riau. This is important to contribute to the studies of the Qadiriyah wa Naqsabandiyah Sufi order which are more focused in Java. ${ }^{3}$ Therefore, this study was conducted with the aim of discovering and explaining the traditions or customs of Qadiriyah wa Naqsyabandiyah followers in Pekanbaru, Riau.

${ }^{3}$ The Tarekat of Qadiriyah wa Naqsyabandiyah in Indonesia is the most influential in the society. This Tarekat has a lot of followers in Nusantara. This Tarekat was developed firstly in Jawa Barat through Syaikh Ahmad Khatib, namely Syaikh Abdul Karim from Banten. Two other students are Syaikh Tholhah from Cirebon and KH. Ahmad Hasbullah from Maduraas well as Muhammad Ismail ibn Abd. Rahim from Bali and Syaikh Yasin from Kedah who then lives in Mempawah, Kalimantan Barat. Others live in Mekah and teaches Islam there. This tarekat also growsin Jawa Tengah through Pesantren Mranggen with the Mursyid ofthe tarekat, Kyai Muslih, who has the spiritual path with Syaikh Abd al-Karim. In Jawa Timur, it also developed through the Pesantren Darul 'Ulum with the mursyid Kyai Romli who obtained certificate from Kyai Kholil of Bangkalan. Nur Syam, Tarekat Petani..., p. 26 
This study is a field study in qualitative form with phenomenology approach. Because of the qualitative-phenomenological nature, this study is done by understanding the pehenomena that appear associated with the habit making the traditions conducted by followers of the Qadiriyah wa Naqsyabandiyah in Pekanbaru, Riau. The study data was collected from various sources, i.e the results of observation, interviews, and documentation.

This study is about the tradition of followers of Qadiriyah wa Naqsyabandiyah in Pekanbaru, Riau. It's departs from the theory of the peaceful coming of Islam in the archipelago brought by Sufi scholars from Arab and Gujarat traders, India. The involvement of Sufi clerics is strongly believed by historians in giving birth to the theory of the development of Islam in the archipelago so as to embody the pattern of cultural Islam. For more details, the framework of this study can be seen from the following models:

Figure 1.1

Framework

The Theory of the Coming of Islam into

Nusantara through Sufi Scholars

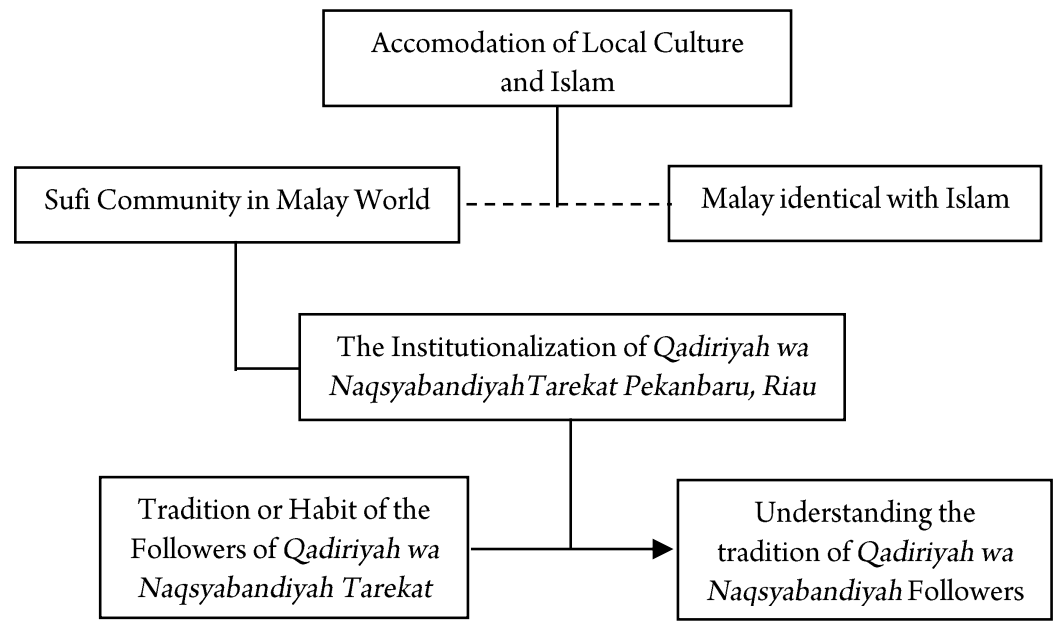

Source: Research Processed Data 


\section{B. The Tarekat, Sufism, and the Propagation of Islam in the Archipelago}

Before comprehending comprehensively the tarekat, it should be understood that the tarekat has a close relationship with the esoteric issues (Sufism). Sufism is essentially a personal spiritual experience, but due to the similarity among scholars in the practice of religion, there is a general guidance about maqamat and $h a l .{ }^{4}$ Even, in the perspective of al-Hujwiri, it is not only maqamat and hal but also tamkin ${ }^{5}$. Maqamat is one of the concepts initiated by the Sufis in the early history of Islamic Sufism. The word maqamat is the plural of the word maqam, which literally means standing place, station, place, location, position or level. While the word ahwal is the plural of the wordhal, which can literally mean condition or state. The broader ahwal can be defined as the mental state experienced by the Sufi during his spiritual journey. ${ }^{6}$ One other thing, namely tamkin, is the abode of the spiritual experts who achieved because of his holiness. ${ }^{7}$

The term tasawaufindeed is related much to the esoteric dimension of man. ${ }^{8}$ Linguistically, Sufism is defined as a mental attitude that always maintains the sanctity of self, worship, simple life, willing to sacrifice for good and always be wise. Such an attitude of the soul is essentially a noble character. Basically Sufism is a teaching that talks about the closeness between the Sufi (human) with Allah the Almighty. According to Lutfi, ${ }^{9}$ in the Qur'an there are several verses that indicate human closeness with Allah the Almighty; one of them is Al-Baqarah verse 186; And if my servants ask you (Muhammad) about Me, then I am near. I grant the petition of the one who prays when he prays to me. Let them fulfill (My commandments) and believe in $\mathrm{Me}$, that they may obtain the truth. In addition, $\mathrm{Lutfi}^{10}$ also quotes

${ }^{4}$ Tatang Abd. Hakim dan Jaih Mubarok, Metode Studi Islam, (PT. Remaja Rosdakarya: Bandung, 2000), p. 161

${ }^{5}$ Ali Ibn Uthman Al-Hujwiri, Kashf al-Mahjub: The Oldest Persian Treatise on Sufism, trans. Suwarjo Muthary dan Abdul Hadi, (Jakarta: Mizan, 1993), p. 330.

${ }^{6}$ Imam Taufiq dalam Ibnu Farhan, "Konsep Maqamat dan Ahwal dalam Perspektif Para Sufi”, Yaqzhan, Vol. 2, No.2, 2016, p. 158

${ }^{7}$ Ali Ibn Uthman Al-Hujwiri, Kashf al-Mahjub..., p. 331.

${ }^{8}$ Abuddin Nata, Akhlak Tasawuf, (PT. Raja Grafindo Persada: Jakarta, 2009), p. 178

${ }^{9}$ Attabik Luthfi, Salam Qur'an: Al-Qur'anul Karim dan Terjemahan Edisi Keluarga (Salamadani: Bandung, 2009), p. 28

${ }^{10}$ Ibid, p. 519 
the Qur'an Qafverse 16; And indeed, We have created man and know what is whispered by his heart, and We are closer to him than his neck.

Related to the tarekat, this term is often understood by two terms namely; first, the spiritual path to God, and this includes the sufistic method of getting closer to God, and second, it is a sacred brotherhood where a number of disciples and teachers are assisted by the murshids. ${ }^{11}$ Thus, as with Sufism, the term tarekat is widely used by Sufism experts. Tariqa means a spiritual path for a Sufi in which it contains the deeds of worship and others on the theme of God and His attributes with deep appreciation. The practice in this Tarekat is aimed at getting as close as possible (in a spiritual relationship) with God.

In subsequent developments, the Tarekat according to Harun Nasution, as quoted by Nata, ${ }^{12}$ contains the meaning of the organization which has the shaykh, ritual ceremonies, and certain forms of remembrance. The teacher in the institutionalized tarekat is called a murshid or shaykh and his deputy is called the caliph, and the disciple is called the followers of the tarekat. While the place of their association is called ribath or taqiyah or zawiyah. Thus, the tarekat has a substantial and functional relationship with Sufism. This group then becomes the institution that gathers and binds a number of followers with certain rules. In other words, the tarekat is institutionalized tasawwuf. As an institutionalized form of tasawwuf, the tarekat is a continuation of the earlier Sufi followers. The change of Sufism into the tarekat as an institution can be seen from the individual, which then develops into a complete tarekat with symbols and elements. The followers or adherents of Sufism are commonly referred to as Sufi communities or followers of the tarekat.

The Tarekat is a living doctrine that will not be separated from the cultural context in which people live. ${ }^{13}$ Herein lies the attractiveness of Islamic teachings of tarekat pattern with Malay culture that has become the guideline of community life. In reality, the world of the Sufi community or

${ }^{11}$ Mulyadhi Kartanegara, Menyelami Lubuk Tasawuf(Erlangga: Jakarta, 2006), p.

${ }^{12}$ Abuddin Nata, Akhlak Tasawuf..., p. 271

${ }^{13}$ The development of Islam according to Nur Syam can not be separated from the role of Sufism. The character of Islam in Nusantara is Islam adapted from Southern India spread by the Sufi followers. Sufi Islam is basically accomodative with local cultures. This character of Islam is different from the character of Islam in the Middle East which is puritant. Nur Syam, Tarekat Petani..., p.4 
tarekat followers is a unique world. The uniqueness can be seen from the phenomena of tarekat life that has a characteristic, namely the esoteric practice of religion. They do not practice religion in its exoteric, formal, rigid, and full of literal textual interpretations, but they practice their religion with an esoteric, profound, flexible (not rigid) style, and full of nativist interpretations. They are religious through feeling, so the sharpened is the heart or the sense not the thoughts that have implications in life. ${ }^{14}$

In the sixteenth and seventeenth centuries, the tarekat had become an important part of the life of the Islamic community in Nusantara. The tarekat that developed in the century include the order of Qadiriyah wa Naqsyabandiyah, Syattariyah, Naqsyabandiyah, Khalwatiyah, Samaniyah, and Alawiyah. The Qadiriyah wa Naqsyabandiyah order was developed by the Sufi of Borneo who lived in Mecca, namely Shaykh Ahmad Khatib Sambasi. He was a successful figure who combined the Qadiriyah and Naqsyabandiyah tarekat. ${ }^{15}$

In the historical record, the role of tarekat in the process of spreading Islam in the archipelago is undeniable, especially on the island of $\mathrm{Java}^{16}$ and to the corners of Sumatra which is more dominated by the Naqsabandi Order. ${ }^{17}$ Most of the scholars and observers of Islam recognize its existence and its enormous role. Contextualization of Islamic teachings makes Islam easily accepted by the local population due to the proximity or commonality between the teachings of Islam and local culture; the Malay is identical with Islam.

Looking at these historical facts, the development of Islam can not be separated with the world of Tarekat. The first Islam that came to the archipelago was the Islamic version of Sufism or sufistic style. It can be identified through several Muslim figures who are attributed as Sufi followers especially in the early days of Islamization in the archipelago; among others were Hamzah Fansuri, Syamsuddin Sumaterani, Abdurrauf alSinkili, and Walisongo on the island of Java. ${ }^{18}$ Tjandrasasmita mentions, ${ }^{19}$ "with these Sufi teachings, Islamic propagators incorporate acceptable teachings by the natives so that the teachings of Sufism are an important

\footnotetext{
${ }^{14}$ Ibid, p. 197

${ }^{15}$ Ibid, p. 25

${ }^{16}$ Ibid, p. v

${ }^{17}$ Abuddin Nata, Akhlak Tasawuf..., p. 274

${ }^{18}$ Nur Syam, Tarekat Petani..., p. 71-72

${ }^{19}$ Ibid, p. 72
} 
factor in its spread". Sufism plays an important role in shaping the Islamic community from the 16th century to the 18th century.

The role of the tarekat followers in the development of Islam in the archipelago can be seen from many figures of spreaders of Islam which were actually the shaykh and murshid of the tarekat. An explorative study conducted by Martin van Bruinessen on the Qadiriyah wa Naqsyabandiyah in the archipelago provides an illustration of how the role of tarekat teachers in the Islamization process in the archipelago. ${ }^{20}$ Therefore, there is no doubt that Islam entered the archipelago through the touch of Sufism. Azra explained that the Islamization in the archipelago that took place peacefully, essentially is the process of Islamization done by the Sufi da'i who indeed have the ability to preach with the model of tasawuf. ${ }^{21}$

Azra, as stated by Nurdinah Muhammad, mentions that the relationship between Muslims in the Malayo-Indonesian and Middle East region has been established since the early days of Islam. Muslim traders from Arabia, Persia and the Indian subcontinent who came to the archipelago not only trade but also to some extent spread Islam to the local people. Penetration of Islam in the more recent times seems done by the Sufi teachers who since the end of the 12th century came into the archipelago. ${ }^{22}$

Although Islam came and flourished in Indonesia for more than five centuries, the understanding and appreciation of Muslim faith still tended to be accommodative; interesting accomodation between the noble values of Islam with local culture. ${ }^{23}$ Although human beings now are influenced by modern values, human religiosity is not entirely detached from the influence of local traditions inherited by the predecessors. Thus, followers of the Nahdlatul Ulama organization tend to tolerate and preserve the customs that accommodate local traditions.

Sufi community as one of the groups engaged in the spreading of Islam, is a group of people who exists and focuses in the development of traditional Islamic values. The development of the Sufi community is characterized by the growing number of groups that are concerned with the development of such traditional societies, such as langgar groups contained

\footnotetext{
${ }^{20}$ Ibid, p. 19

${ }^{21}$ Azyumardi Azra, Jaringan Ulama Timur Tengah dan Kepulauan Nusantara Abad XVII dan XVIII, (Mizan: Bandung: 1995)

${ }^{22}$ Nurdinah Muhammad, "Karakteristik Jaringan Ulama Nusantara Menurut Pemikiran Azyumardi Azra”, Substantia, Vol. 14, No. 1, April 2012, p.76

${ }^{23}$ Tatang Abd. Hakim dan Jaih Mubarok, Metode Studi Islam..., p. 189
} 
in ribat, khanaqah, or zawiyah which are all known as places of practicing Sufism. The Sufi community is generally referred to the tarekat followers, essentially it is a form of institutionalization or the organization of tasawwuf or Sufism in particular. $^{24}$

As an organization, the Sufism or tarekat community has a structure, ${ }^{25}$ leadership system, and succession, as well as certain ritual methods. Broadly speaking, at the top of the leadership structure there is a sheikh or murshid; then the Caliph, and then the members in general. The solidarity and compliance of the tarkeat not only rests on the doctrine of Sufism itself, but also on the total adherence of the members to the shaykh or murshid. For example, any salik or those wishing to travel a spiritual path through the tarekat should perform bay'ah or oaths allegiance to the shaykh or vicegerent of his caliph. Thus, the tarekat then becomes a relatively solid institution or organization. The solidarity of the tarekat then spawned it as a multifunctional organization; can be used for various purposes, depending on the will or aspirations of the tarekat leader himself.

\section{Pekanbaru, Riau: A Contest of Islam and Malay Identity}

In Malay world, Malay language has become an important Islamic language. This encourages Sufi literature to play a definitive role in shaping Malay into an Islamic language. ${ }^{26}$ How is it with Pekanbaru who became the provincial capital associated with Islamic identity?. Pekanbaru is a city that is experiencing rapid development. No wonder the population comes from a variety of cultural backgrounds. Its heterogeneous nature marks the character of Pekanbaru as a city that constantly produces diversity of ideas, actions and religious behavior. On the other hand, residents of Pekanbaru are often mentioned to have a distinctive identity. The identity is called Malay.

However, in this article it is very important to explain about the Malay society conceptually. There are various terms about Malay, of which comes from the word mala (meaning mula) and yu (which means country), as it is attributed to the word Ganggayu which means the Ganga country. In

\footnotetext{
${ }^{24}$ Azyumardi Azra, Menuju Masyarakat Madani: Gagasan, Fakta, dan Tantangan, (PT. Remaja Rosdakarya: Bandung, 2005), p. 37

${ }^{25} \mathrm{Ibid}$, p. 38

${ }^{26}$ Seyyed Hossein Nasr, The Garden of Truth: The Vision and Promise of Sufism, Islam's Mystical Tradition, (New York: HarperCollins Publishers, 2007), p.141
} 
another opinion, the word Malay or melay in Tamil means high ground or hill, beside the word malay which means rain. This corresponds to the Malay countries at first located in the hills. Whereas in Javanese, the word Malay means running or walking fast. Meanwhile, in Chinese the word malay is matched with the word mo-lo-yeu which is defined as an adult kingdom. Traditionally, Riau Malays are recognized as local indigenous people. Because the dominant view is the Malay and Malay culture in everyday life, then the people of Riau are known as the Malay community. Although the people of Riau are known as Malay people, but the people of Riau are actually a region whose population consists of various origins and ethnics. Thus as a society, Malay is a plural society. ${ }^{27}$

The term Malay or Malay can be divided into several categories or conditions $^{28}$. Malay people can be distinguished between Old Malay (proto melayu) and young Malay (deutro melayu). Old Malay was the first Malay to come to the Malay archipelago. Malay ancestors are estimated to arrive and settle around the year 3000-2500 BC. While the Young Malay came in the year 300-250 BC with a large number of them inhabiting the coast and river watershed which become the centre of trade traffic. Therefore, they are opener than Old Malay, so it is easy to marry with folk or other ethnics, which also opens the opportunities for the absorption of cultural values from the outside. This has implications for social systems and value systems that continue to change as time changes.

In further developments, the Malay people who inhabit the coastal areas and the river basin initially embraced animism and dynamism. However, with the coming of Islam the Malay people prefer to embrace a new religion, i.e Islam. The arrival of Islam has given new spirit to them by establishing Malay kingdoms along the rivers in Riau so that it is recognized some of the folk or Malay community in this area, one of them is: RiauLingga Malay, who inhabits the former Riau-Lingga kingdom which isa part of of Riau Islands, Karimun, and Natuna. Most of them married with the Bugis and cross-ethnics in the 18th century; Siak Malay inhabited the former Siak empire, which is largely a watershed area. Most of them married with Arab descendants; Kampar Malay inhabited the Kampar stream area. Some of them had relationships with Minangkabau and Javanese ethnic groups during the Japanese occupation; Inderagiri malay inhabited the Inderagiri

${ }^{27}$ Attabik Luthfi, Salam Qur'an: Al-Qur'anul Karim dan Terjemahan Edisi Keluarga, (Salamadani: Bandung, 2009), p. 455

${ }^{28}$ UU Hamidy, Melayu Riau, (Unri Press : Pekanbaru Riau, 1998), p. 13 
kingdom of Inderagiri watershed in which some of them have marital relations with Banjar ethnic and Arab descendants; Rantau Kuantan Malays inhabited Kuantan river / river area; Petalangan Malays inhabited in the forestand several branches of the river in the area of Pangkalan Kuras. ${ }^{29}$

Malay or Malay people recognize their personality identity including Malay customs, Malay language, and Islam. Thus, a person who claims to be a Malay must have Malay customs, Malay language, and Muslim. Some characteristics of Malay society are: Malay society especially deutro Malay is very open to various social and cultural values adopted and brought by other society; so it is easy for them to marry with other ethnics. This provides the opportunities to the absorption of cultural values from the outside; and the young Malay people prefer to inhabit the crowded coastal areas of foreigners who become the centre of trade traffic. ${ }^{30}$

Therefore, Malay culture is open and accommodative to the elements of culture that come from outside which coexists in the diversity of social and cultural identity. Islam became the core of Malay culture that strengthened Malay identity. Malay morals also serve as moral guidelines in personal and social life. This Malay culture focuses more on efforts to maintain good relationships with fellow members of the community in order to create harmony and social order, so that this style of culture affect the personality of Malay. ${ }^{31}$

Malay cultural characteristics that are open and accomodative towards the differences resulted from the history of Malay cultural experience that for centuries has been in contact with various foreign cultures. So it is not surprising that many Malay cultures come from nonMalay traditions. ${ }^{32}$

Thus, along with encounters with other cultures, Malay identity undergoes a process of acculturation and adaptation that is often referred to the term 'cultural hybridity'. Mixing with other cultures makes Malay as a contesting ethnic term. Moreover, today the term 'malay' which is often attached with Riau Malay as ethnic culture is often compared with other Malay identities which also exist, for example Jambi Malay and so on. In that

\footnotetext{
${ }^{29}$ Ibid, p. 14-19.

${ }^{30}$ Suhaimi, dkk., Pengantar Studi Tamaddun Melayu, (Unri Press: Pekanbaru Riau, 2008), p. 4

${ }^{31}$ Budisantoso, dkk., Masyarakat Melayu Riau dan Kebudayaannya, (Pemerintah Provinsi Riau: Pekanbaru, 1986), p, 455

${ }^{32}$ Ibid, 459
} 
context, in Pekanbaru, the term Malay does not merely refer to 'pure' Malay, but Malays who have experienced of crossing and mixing with other ethnic groups.

\section{The History of Tarekat Qadiriyah wa Naqsyabandiyah in Pekanbaru, Riau}

Historically, the teachings of the Qadiriyyah wa Naqsyabandiyah tarekat in Riau Province-particularly in Pekanbaru City-were brought and developed by KH. Afandi (d.1960) which has the focal point in Desa Insit, Selat Panjang. K.H. Afandi is a student of K.H. Siraj (Johor Baru, Malaysia). K.H. Afandi or known as Shaykh Afandi and among the extended family known as "Mbah Imam", initially developed the teachings of this tarekat for the Tebing Tinggi, Bengkalis, Siak and Rokan Hilir areas, including Pekanbaru City.Since this time the tarekat was first developed in Riau, then Tebing Tinggi sub-district which was still under Bengkalis Regency became the center of meeting of tarekat in Riau area. Therefore, it is not uncommon for many people to conclude that K.H. Afandi is a tarekat founder in the Riau region, ${ }^{33}$ which was later developed by his student, K.H. Mu'thi, for the Siak River Bandar area. As a caliph who continues to develop this Tarekat, K.H. Mu'thi, pledged several disciples, one of them was K.H. Syarifuddin, son of K.H. Afandi who was mandated a will to develop the tarekat in the region of Semukut and its surrounding areas.

The Qadiriyah wa Naqsyabandiyah Order in Pekanbaru City was developed by a caliph who came from one of the regions in the District of Meranti Islands, namely KH. Syarifuddin. In 1996 KH. Syarifuddin recruited KH. Maqsudi to be the Caliph ${ }^{34}$. KH. Maqsudi developed this tarekat through the institution of pesantren education, Nurul Huda AlIslami Pekanbaru. Through this pesantren, the teachings of the tarekat then expanded to several areas around Pekanbaru City, namely Rumbai, Sungai Pagar, and Tapung. The last two areas belong to Kampar Regency.

As a khalifah, $\mathrm{KH}$. Maqsudi who is also the leader of the boarding school, has at least 40 people around the community. Likewise with teachers in boarding schools, the majority have become the tarekat followers. The pesantren is located in Marpoyan Damai, precisely on Jalan Handayani Pekanbaru. In Mataram village,the tarekat members reached 50 people and

\footnotetext{
${ }^{33}$ Interview with H. Syahid,30 Oktober 2014

${ }^{34}$ Interview with H. Syahid, 30 Oktober 2014
} 
in Sei Pagar there are about 10-15 people. But this number continues to grow to other areas, such as Jl. Garuda Sakti and other areas of Kampar regency. ${ }^{35}$

According to K.H. Jamaluddin, grandson of K.H. Afandi, as well as the present khalifah of the region in the district of Pulau Merbau, from the beginning of the Tarekat of Qadiriyah wa Naqsyabandiyah in the area until the death of K.H. Syarifuddin (d. 2006), the Sufis community of tarekat followers still use Semukut, Tebing Tinggi as the only place of haul (annual meeting for memorization of the shaykh and the founder tarekat). During the period of his leadership and especially before his death, K. H. Syarifuddin had recruited not less than 10-13 caliphs. They are K.H. Zuhri Hamid ( Dataran Tinggi Barat), K.H. Soleh and K.H. Khulaini (Belitung / Mengkirau), K.H. Sahil (Bandar Sungai), K.H. Irsyad (Bandar Sungai), K.H. Jamaluddin (Semukut), K.H. Sarbaini (Sidomulyo), K.H. Zainuddin (Topang), K.H. Maqsudi (Pekanbaru), and others. Through these caliphs, the Qadiriyyah wa Naqshbandiyyah order continues to grow. To anticipate such widespread development, the caliphs were permitted to hold haul separately according to the authority given to their respective regions. ${ }^{36}$

\section{E. The Tradition of the Qadiriyah wa Naqsabandiyah Tarekat in Pekanbaru, Riau}

The Qadiriyah wa Naqsyabandiyah order is not an institution which is same as religious organizations such as Nahdlatul Ulama and Muhammadiyah. Nahdlatul Ulama is a religious social organization that runs traditional religious teachings. The followers of NU (Nahdliyin) are people who practice the teachings of tarekat. While Muhammadiyah is more attached to rationality and modernity that sometimes ignores religious traditions identical to Sufism. The Tarekat puts more emphasis on the context of the teachings or practices that its followers must follow. This fact, indicates that the tarekat is not an institution of da'wah or other religious social organization as mentioned above so that the tarekat does not develop as the development of religious social organizations that exist in Indonesia.

The interesting phenomenon of the Sufi followers of the Qadiriyah wa Naqsyabandiyah Order in Pekanbaru City is that the followers of the tarekat which were previously dominated by the Javanese society have now

\footnotetext{
${ }^{35}$ Interview with Nurkhasani and Abdul Munir, 20 Oktober 2014

${ }^{36}$ Interview with K.H. Zuri Hamid, 20 Oktober 2014
} 
been widely followed by other ethnic societies. As the teachings that practice certain spiritual values, the tarekat becomes an attraction for the people because it has unique characteristics, namely to practice the dhikr which has a reference or relationship (genealogy) to the teacher or caliph. The difference with the practice of ordinary people is that there is a clear transformation of the teachings from the teachers to the students or jama'ah. The uniqueness of this practice is the attraction for ordinary people to follow and become tarekat members. In other words, the development of tarekat is strongly influenced by the practices taught through various activities involving the wider community, such as tawajuhan, khataman, and khoul (weekly, monthly and yearly meeting for all members of the Tarekat) by bringing kyai from Java Island. Here's an interview with $\mathrm{KH}$. Nurkhasani, a tarekat badal who is in the village of Mataram Tapung. ${ }^{37}$

"The development of tarekat in Mataram village is quite good and people enter the tarekat with their own consciousness but there is also the result of public invitation with the status of tarekat members. Currently tarekat followers in the village of Mataram are about 40 members "

The tarekat members led by $\mathrm{KH}$. Maqsudi are not only limited to Pekanbaru City but they come from certain areas such as Kampar Regency and Duri Bengkalis City. The general public's interest in following the teachings of the tarekat is more influenced personally or internally by "Malay character". In addition, their observations of the activities undertaken by the tarekat community also encourage such interest. This is the impetus why then this doctrine continues to evolve even though tarekat not as a da'wah institution. This can be seen from the practice of the teachings of the tarekat that develops and sometimes becomes the "icon" for the Malay Community easily blended in the society.

The high religious awareness of the Malay community reinforces the existence of the teachings of the tarekat so that it develops. But these developments are not in quantity perspective, but which are far more important in terms of quality. Therefore, people who join the tarekat members always make a big contribution related to building a harmonious life with others. This fact is evidenced by the absence of social conflicts that occur in the followers of tarekat Qadiriyah wa Naqsyabandiyah either in the

${ }^{37}$ Interview with H. Nurkhasani, 13 November 2014 
city of Pekanbaru or areas that became the development of this teaching, namely Tapung Kampar regency. ${ }^{38}$

The interview result shows that the followers of tarekat in Pekanbaru City and other areas reach hundreds of people, that is around 4045 people in Pesantren Nurul Huda Al-Islami and 40-50 people in Kampung Tapung area.

1. The Pesantren as the Center of Tradition of Tarekat

Pesantren educational institution is the most important institution in developing the teachings of tarekat, as well as the tarekat of Qadariyah wa Naqsyabandiyah in Pekanbaru City. As is known, KH. Maqsudi is the founder of Nurul Huda Al-Islami Islamic Boarding School Pekanbaru which currently has approximately 400-500 students and 60 teachers. Most teachers have become members or followers of this tariqa. While the santri, even though they are not members of the tarekat, yet they have practiced the teachings of the tarekat as taught by the teachers, even though they regard as ordinary deeds and certainly not exactly the same as the actual tarekat practice. At least the style of worship, zikir, and prayers of santri always refers to the views of teachers affiliated with the tarekat.

Educational institutions through developed educational communication make an important contribution in the development of tarekat members. Educational communication is done through the teaching system at pesantren educational institutions such as curriculum boarding schools, teaching patterns, and the interaction of students and kyai. Becausethe boarding school is a place where people gather to study religion, so he has a clear structure and system, especially the leader of the room becomes guidance and role models of students.

2. Member Recruitment Tradition

The recruitment system of membership in the Qadiriyah wa Naqsabandiyah tarekat is passive. This means that tarekat does not expand the teachings to the community to increase the number of members. It all depends on the person who has the intention and desire to become a member. Thus, there is no compulsion in the recruitment system and everything is highly dependent and is based on the sincerity of the people who will become members. Therefore tarekat does not invite but accept so it depends on the interest of someone. However, there are the badal

\footnotetext{
${ }^{38}$ Interview with Nurkhasani, 13 November 2014
} 
behaviors to remind and motivate people who are considered potential to participate in tarekat membership.

If studied more deeply it can be understood that in the recruitment system the tarekat of Qadiriyah wa Naqsabandiyah uses interactional pattern of passive communication. In its application the membership recruitment system also occurs when the badal has a principle that does not show its identity in the midst of the wider community. With this system people only see the behavior of the badal and followers of other tarekat, so unwittingly it affects the wider community to join the tarekat. That is why in a family there is a someone who becomes members and others do not. This happens because there is no necessity for members of the Tarekat to invite other people to become members unless they only motivate others until the person feels interested in being the members of the tarekat. To support and foster a sense of interest in the tarekat for the wider community, members of the tarekat are encouraged to practice the religious teachings. It aims to invite a sense of curiosity of a person so that the person then slowly wants to join the tarekat.

\section{The Tradition of Practicing the Religious Deeds}

In terms of establishing the teachings of the Qadiriyyah wa Naqsyabandiyah tarekat, the followers of this tarekat practice some customs of worship as deeds that must be done in everyday life. The practice is a habit of worship so that it becomes characteristic that a person has become a member of tarekat and distinguish them from the practice of society in general. Some deeds that are performed as a religious routine for tarekat followers are as follows:

The teaching system of the Qadiriyah wa Naqsabandiyah order is basically done in a structured way. The Caliph had an obligation to teach the deeds required by visiting the badal and the tarekat members in order to teach deeds and to evaluate the developments of the practices with the escort of the badal. This system further gives the impression of education so that communication is built more structurally. It means that communication is done from top to bottom or vertical. The Badal is authorized to guide members of the tarekat to the extent of the activities of monthly tawajuh and khataman. The Badal is not given authority to teach deeds except to foster the deeds taught by the caliph. Therefore, the badal always reminds the members of the tarekat to always remember the teacher, with the aim that they practice the teachings of his teachers or caliphs. 
In addition to vertical communication, it is also found the pattern of educational communication. This pattern reflects the necessity of the members of the tarekat to respect the teacher. The teachings that arise are the establishment of attitudes, obedience, discipline, sincerity, and others. The teaching system of this tarekat gives commitment or obedience to the worship practice of the members of the tarekat. Thus theyare not justified to practice the deeds other than those taught by the caliph except to correct the grammatically incorrect sayings. This should only be done by members have the ability of Arabic language.

As revealed by H. Syahid, ${ }^{39}$ the system of teaching in Qadiriyah wa Naqsyabandiyah can be done through practice in the event khataman and tawajuhan, i.e face to face interaction between the teacher (shaykh / mursyid) with students (salik) to conduct activities related to tarekat. For the practice of khataman, the followers of the Qadiriyah wa Naqsyabandiyah conduct on this practice differently, especially from the time of its execution. The followers of the Qadiriyah wa Naqsyabandiyah Order of Pekanbaru City which is located at Pondok Pesantren Nurul Huda Al-Islami performs a ceremony every Friday night. However, in Mataram and Sei Pagar, it is held on Tuesday and Thursday nights.

4. The Tradition of Social Relations

The social relationships established by the Sufi community are in fact almost the same as the social community in general. They work, socialize, communicate, interact, and socialize with anyone. There is no significant difference in relation to this social relationship. The very positive thing is that the followers of the tarekat, though limited in number, are able to be role models or social figures who always take a high position in religious matters, for example for the position of ulama, imam, amil, ustaz, and other religious leaders so that it becomes a place to question all religious issues.

The phenomenon illustrates that the followers of the Qadariyah wa Naqsyabandiyah tarekat are inseparable parts of the society in which they live. Therefore, all forms of religious social activity involving the whole society, tarekat followers are also involved in it. As part of the community, followers of the Qadariyah wa Naqsyabandiyah are not found to be in conflict with other communities. Therefore, conflict in the Malay society is

\footnotetext{
${ }^{39}$ Interview with H. Syahid, 30 September 2014
} 
very rare. Even if there is, it is only related to personal problems not because of the teachings and practices of the tarekat that developed in the area. ${ }^{40}$

In the teachings of the tarekat, an invitation to get closer to Allah SWT is emphasized by doing deeds, good deeds associated with human relationships and practices associated with the relationship with the Creator. Tariqa followers are not only required to focus on God, but also must respond to social problems. In Malay culture is known tradition of "gotong royong". Attention to the problem of social relations is the true identity of tarekat followers. It is no exaggeration if Ustadz Nurkhasani, as badal and $\mathrm{H}$. Syahid, as well as followers of the tarekat at Pondok Pesantren Nurul Huda Al-Islami Pekanbaru, said that it is not true if there is an assumption that the tarekat makes his followers exclusive and focus for himself. Instead, the tarekat teaches followers to respond to social conditions. From these two Qadiriyah wa Naqsyabandiyah tarekat figures it can be understood that, in fact in the perspective of the teachings of thetarekat human beings are given the right to engage in social relationships with their neighbors well, i.e placing their position as human beings who can give and help their fellow Muslims.

In general, the Sufi community of the followers of the Qadiriyah wa Naqsyabandiyah in Pekanbaru and its surroundingsindeed display a harmonious and peaceful life. They always present simplicity in social life. The community of the tarekat has contributed greatly to a harmonious life with others. This fact is evidenced by the absence of social conflicts that occur in the community of Sufi followers of Qadiriyah wa Naqsyabandiyah Order in Pekanbaru City and surrounding areas.

The Qadiriyah wa Naqsyabandiya Order takes the principle of maintaining good social relations with fellow members and society. In the tarekat there is no problem with other people. Members often show behavior that blend in with the community. Such behavior provides interpersonal communication patterns with two-way communication patterns but is passive in nature. Internally this communication behavior appears in the activities of khataman and belasan. While externally this communication pattern creates a role model for the society to follow the way and behavior of the tarekat followers.

This fact can be seen in various social activities such as gotong royong, social activities of death, religious holidays, and so forth. And in

\footnotetext{
${ }^{40}$ Interview with Nurkhasani, 16 November 2014
} 
every social activity, the followers of tarekat always are being chosen asa leader who "one step more" to lead the event and the activity. The community's trust in the involvement of members in the community causes this organization as a role model by ordinary people. This brings the harmony or good social relations between people and communities. In addition, it also brings good interaction with the local government.

In this context, it can be understood that the followers of the Qadariyah wa Naqsabandiyah Order in Pekanbaru do some customs such as the tradition of not asking (power or economic resources), but can be passive; based on ethics; being a role model; being active in socialrelationship; being obedient to the leader so that communication becomes more directed and controlled; etc.

\section{The Tradition of Communication}

Regarding to the communication pattern of followers of Qadariyah wa Naqsabandiyah can be summarized as follows;

First, in relation to Qadariyah wa Naqsabandiyah as apart of the Sufi community in Pekanbaru it can be seen that this tarekat is more likely to use, borrowing the term Mulyana, the wheel pattern in communicating. The wheel pattern implies that the accessibility of tarekat followers is still low, loyalty to the group is very high, promoting the Islamic moral excellence, highlighting the importance of leaders, trying to be as wise as possible in solving the problem, have a high consistency in charity and work, not much talk, not ambitioous, not too interested in change, and very responsive to social problems.

Secondly, in relation to social relations it can be understood that the followers of tarekat Qadaryah wa Naqsabandiyah in Pekanbaru communicate with an "interactional" pattern. This pattern of communication implies that in relation to social life tarekat followers have a habit of communicating that is not "ambitious" on how much communication is spoken but how the quality of communication is influential and effective for others. Some indicators related to this are; the habit of not asking, but being selective and careful; passive ethics, but to be a role model so that others become interested; the habit of not communicating individually, etc.

The two communication patterns of the followers of the Qadariyah wa Naqsabandiyah order mentioned above are reflected in the vision of worship that focuses on charity as a habit; organizational development 
system that promotes interactional communication through educational institutions, and social relationships; a structured and vertical teaching and education system, a passive membership recruitment system; a wise conflict resolution system that accentuates the habit of "withdrawing" and putting forward the "wong tuo" philosophy; and responsibility to the environment and nature based on the principle of "not destructive" and put the nature as a partner because they feel it as a creature of Allah SWT. Thus, the notion that the followers of the tarekatare ignorant on social issues needs to be revisited.

\section{The Tradition of Conflict Resolution}

In the Qadiriyah wa Naqsabandiyah Order, one of the techniques of resolving conflict is by silence until the conflict subsides on its own. Therefore, in the tarekat very small differences occur. Furthermore, this tarekat also applies the way of "withdrawing" or avoiding the problem of potential conflict so that social relations become harmonious, peaceful and well preserved.

Symbolic communication patterns reflect the expertise of tarekat followers as people who are considered capable of resolving the potential for conflict either in the family environment, pilgrims, and the wider community. The symbol of "wong tuo" as a conflict resolver indicates the importance of peaceful life by promoting good interaction between human beings.

The followers of the tarekat are always entrenched with neutral spirit if there are two or more potential conflicts. In tarekat, ethics is taught by promoting the necessity to control the lust as a source of conflict through dhikr in the heart and mind. Nevertheless for this tarekat someone who can control the potential of conflict with others is also determined by the absence of interpersonal conflict.. This means a person should havethe selfcontrolling under the supervision of the Creator. Thus, the person who can control his interpersonal conflict, he must be able to reconcile a conflict with others. In other words, to reconcile with others as well as to reconcile with the environment, one must first reconcile through his heart with his Lord.

\section{Tradition of Environmental and Natural Management}

This tarekat is very concerned with the environment. For this tarekat the surrounding natural environment becomes a partner in getting closer to God. They regard nature as a creature of God who also worshiped Him. Therefore, the tarekat teaches the necessity to be friendly with nature. 
They feel unethical when destroying nature so that they do not regard nature as an exploited object.

This tarekat is not an organization assigned to manage nature but it really has a good attitude and behavior towards the environment. This is because, in Sufi teachings, it is important for a follower to do good with nature. Nature for tarekat followers should be arranged and managed in such a way so as not to disturb their worship. Therefore, a conducive environment for tarekat followers is an important thing to increase the worship.

The followers of tarekat usually tend to be happy with the cleanliness of the environment, residence, public facilities and so on. In order to realize this the followers of the tarekat put forward social interaction culture in doing matters related to socio-environment. The habit of tarekat followers is closely related to care about the environment. But, there are some members who may have a deviant behavior of detructing the nature. For the followers of the tarekat, the beautiful environment is a picture of the beauty of one's relationship to their God. Green environmental conditions teaches the peacefulness of prosperity and sincerity.

\section{F. Conclusion}

The tradition of followers of the Qadiriyah wa Naqsabandiyah Order in Pekanbaru, Riau is centered in the Islamic boarding school or Pondok Pesantren. Through the pesantren, the tarekat tradition is spread gradually through educational and socialization practices. Traditions or customs are then developed into the surrounding community. By placing the pesantren as the center of tradition, the tarekat symbolically wishes to inform the public that the tarekat is in fact a doctrine close to Islamic education. Thus, people's doubts about possible 'deviations' in the tarekat do not occur.

The Pesantren as a center for tarekat development means placing pesantren as an 'icon' of Islamic education development that is close to the education of Sufi character. Sufi educational values are increasingly crucial today amid the consumptive patterns and lifestyles that flourish from modernization, capitalism, and globalization.

The study of the Sufi community, especially the tarekat, did not recognize its completion. Although the development of this community is not measured in terms of quantity, but the quality. This tarekat focuses on the quality of its contribution in a society. Therefore, similar studies need to 
Masduki, dkk

be continuously conducted so that the "uniqueness" of the tarekat can truly be revealed and can be better known by various parties so that its contribution can be understood. [] 


\section{Bibliography}

Al-Hujwiri, Ali Ibn Utsman, Kasyf al-Mahjub: The Oldest Persian Treatise on Sufism, trans. Suwarjo Muthary dan Abdul Hadi, Mizan: Jakarta, 1993.

Arifin, Anwar, Dakwah Kontemporer Sebuah Studi Komunikasi, Graha Ilmu: Yogyakarta, 2011.

Azra, Azyumardi, Menuju Masyarakat Madani: Gagasan, Fakta, dan Tantangan, PT. Remaja Rosdakarya: Bandung, 2005.

Azra, Azyumardi, Jaringan Ulama Timur Tengah dan Kepulauan Nusantara Abad XVII dan XVIII, Mizan: Bandung: 1995.

Baldick, Julian, Mystical Islam: An Introductuion to Sufism, New York University Pres: New York and London, 1992.

Budisantoso, dkk., Masyarakat Melayu Riau dan Kebudayaannya, Pemerintah Provinsi Riau: Pekanbaru, 1986.

Connoly, Peter, Approaches to the Study of Religion, Cassel: London. 1999.

Farhan, Ibnu, "Konsep Maqamat dan Ahwal dalam Perspektif Para Sufi", Yaqzhan, Vol. 2, No.2, 2016.

Hakim, Tatang Abd., dan Jaih Mubarok, Metode Studi Islam, PT. Remaja Rosdakarya: Bandung, 2000.

Hamidy, UU, Melayu Riau, Unri Press, Pekanbaru Riau, 1998.

Heidegger, Martin. Being and Time, trans. John Macquarrie and Edward Robinson. HarperCollins Publisher: New York, 1962.

Kartanegara, Mulyadhi, Menyelami Lubuk Tasawuf, Erlangga: Jakarta, 2006).

Luthfi, Attabik, Salam Qur'an: Al-Qur'anul Karim dan Terjemahan Edisi Keluarga, Salamadani: Bandung, 2009.

Masduki, Humanisme Spiritual: Paradigma Penngembangan Masyarakat Islam dalam Filsafat Sosial Nasr, Referensi: Ciputat, 2013. , Pengamalan Agama Masyarakat Islam Perkotaan: Fenomena dan Strategi Pengembangan, Pekanbaru: Unri Press, 2008

Muhammad, Nurdinah, "Karakteristik Jaringan Ulama Nusantara Menurut Pemikiran Azyumardi Azra”, Substantia, Vol. 14, No. 1, April 2012. 
Mulyana, Deddy, Komunikasi Organisasi: Strategi Meningkatkan Kinerja Perusahaan, PT. Remaja Rosdakarya: Bandung, 2001.

Nasr, Seyyed Hossein, The Garden of Truth: The Vision and Promise of Sufism, Islam's Mystical Tradition. HarperCollins Publishers: New York: 2007.

Nata, Abuddin, Akhlak Tasawuf, PT. RajaGrafindo Persada: Jakarta, 2009.

Suhaimi, dkk., Pengantar Studi Tamaddun Melayu, Unri Press: Pekanbaru Riau, 2008.

Syam, Nur, Tarikat Petani: Fenomena Tarikat Syattariyah Lokal, LKiS: Yogyakarta, 2013. 